\author{
EWA JOHNSSON \\ ORCID 0000-0002-2560-7568 \\ Uniwersytet im. Adama Mickiewicza \\ $w$ Poznaniu
}

\title{
DZIECIŃSTWO W MAROKU
}

AbStRact. Johnsson Ewa, Dzieciństwo w Maroku [Childhood in Morocco]. Studia Edukacyjne nr 60, 2021, Poznań 2021, pp. 177-197. Adam Mickiewicz University Press. ISSN 1233-6688. DOI: 10.14746/ se.2021.60.10

This paper is devoted to outlining the child's situation in the Moroccan socio-cultural reality through the prism of its marginalization. Various factors such as cultural and religious conditions, the family - its structure and economic status, legislative solutions - Family Code Mudawwana, marriage institution, lack of official status, migration, employment, health care and access to education combine to create a map of influences causing specific consequences in the family, in biographies of mothers and finally their children. The purpose of this paper is to produce this map of the problems of today's Morocco and to make the reader aware of the tragedy and enormity of powerlessness experienced by marginalized, excluded and invisible children. The analysis was based on studies, the latest thematic reports as well as press reports, excerpts of literary texts reflecting the reality of Morocco, or online publications of non-governmental organizations.

Key words: childhood, Morocco, marginalization, cultural and social context

\section{Wstęp}

Prezentowany artykuł został poświęcony jednemu z aspektów marokańskiego dzieciństwa w ujęciu konstruktu społecznego - marginalizacji w różnych jej aspektach jego życia, będącej zarówno wynikiem uwarunkowań pierwotnych, jak i wtórnych. To przede wszystkim rodzina wpływa na biografię każdego dziecka i choć reprodukcja ról oraz statusu społecznego nie jest koniecznością, to inne scenariusze życia dla dorastających młodych ludzi, na przekór uwarunkowaniom, wymagają determinacji i poświęcenia zarówno ze strony rodziny, jak i ich samych. Podstawę analizy uwarunkowań dzieciństwa stanowią „druki zwarte” - przykłady prozy, raporty, artykuły oraz opracowania zamieszczone online, dotyczące pośrednio i bezpośrednio sytuacji dziecka 
w kulturze arabskiej i w Maroku. Poszczególne kategorie tworzą swoistą, płynną mapę wyzwań dla marokańskiego społeczeństwa, rządu i licznych, dobrze w Maroku funkcjonujących - zarówno narodowych, jak i zagranicznych - organizacji pozarządowych podejmujących role, które w społeczeństwach świata zachodniego są zwykle zarezerwowane dla państwa.

Według najnowszych danych statystycznych, szacunkowa liczba ludności Maroka wynosi obecnie 36175644 mieszkańców ${ }^{1}$, w tym - jak podaje UNICEF (dane dla $35 \mathrm{mln}$ mieszkańców) - populacja dzieci w wieku od 0 do 17. roku życia stanowi jedną trzecią ogólnej liczby ludności². Są to dane oficjalne. W przypadku Maroka wszelkie dane statystyczne mają jednak charakter orientacyjny, gdyż chociażby dzieci urodzone poza związkami małżeńskimi i nieuznane przez ojca znajdują się poza tymi danymi i w związku z tym są ",niewidzialne” dla większości instytucji. Pomimo stopniowej poprawy sytuacji matek i dzieci w Maroku nadal można odnotować znaczące dysproporcje pomiędzy statusem rodzin najuboższych ekonomicznie a statusem tych uprzywilejowanych, zamieszkujących $w$ dzielnicach willowych dużych miast.

Trzeba mieć również na uwadze, że rekonstrukcja wizji dzieciństwa w wieloetnicznym, wielokulturowym i tym samym wielojęzycznym kraju (zob. E. Johnsson, 2018)³ , jakim jest Maroko, będzie zawsze uogólniona i jednocześnie subiektywna, stanowiąca deskrypcję arbitralnie wybranych elementów tego konstruktu. Takie spojrzenie na warunkowane kulturowo zjawiska i role społeczne z pewnością pozwala na odczytanie jedynie dominujących tendencji i zależności pomiędzy poszczególnymi elementami danej struktury. Ponadto, upływ czasu określa zmienność powyższych determinantów. Indywidualne biografie będą więc w mniejszym lub większym stopniu wpisane $\mathrm{w}$ tak naszkicowane ramy.

Losy dziecięce, choć spolaryzowane w marokańskiej rzeczywistości, można ująć we wspólną narrację - obraz dzieciństwa w Maroku. Beztroskie dzieciństwo - pełne rodzicielskiej miłości, dobrobytu, z dostępem do edukacji i zabawy - jest $w$ tym kraju wciąż przywilejem, a nie rzeczywistością. $Z$ jednej strony tradycja, zarówno Amazigh ${ }^{4}$, arabska, jak i tradycja przekazywana

\footnotetext{
${ }^{1}$ Horloge de la population, Haut-Commissariat au Plan du Maroc. Centre National de Documentation, www.hcp.ma. [dostęp: 10.02.2021].

2 Les enfants au Maroc. Des progrès et des défis, UNICEF; https://www.unicef.org/morocco/rapports/analyse-de-la-situation-des-enfants-au-maroc/les-enfants-au-maroc, [dostęp: 10.02.2021].

${ }^{3}$ Zob. E. Johnsson, Uwarunkowania społeczne i jezykowe dla edukacji w Maroku, [w:] Edukacja w warunkach globalnych i lokalnych. Konteksty i egzemplifikacje, red. A. Boroń, A. Mańkowska, C. Czech-Włodarczyk, P. Peret-Drążewska, Poznań 2018, s. 123-141.

${ }^{4} \mathrm{~W}$ tekście będę używała terminu Amazigh (Imazighen l.mn.) na określenie rdzennej ludności zamieszkującej między innymi Królestwo Maroka, termin berber jest przez diasporę Imazighen odbierany jako pejoratywny.
} 
$\mathrm{z}$ pokolenia na pokolenie $\mathrm{w}$ rodzinach mniejszości etnicznych, oraz religia (przede wszystkim islam), regulują społeczne postrzeganie i funkcjonowanie dziecka w Maroku. Z drugiej strony, zmienność rzeczywistości i globalizacja wywierają zarówno pozytywny, jak i negatywny wpływ na marokańskie społeczeństwo, powolnie zmieniając uwarunkowania nie tylko marokańskiego dzieciństwa, ale i funkcjonowania wszystkich Marokańczyków. Przykładem tych zmian może być choćby transformacja modelu marokańskiej rodziny i związane z tym procesem konsekwencje. Dzieciństwo z perspektywy socjokulturowej stanowi więc konstrukt wynikający z kontekstu kulturowego, $\mathrm{w}$ jakim jest rekonstruowane, ze zmienności czasu ${ }^{5}$, ale też skutek zróżnicowania uwarunkowań geograficznych, które w Maroku istotnie kształtują jego jakość. Na przykład, wysokie i trudno dostępne masywy gór Atlas regulują życie mieszkańców zgodnie z rytmem przyrody, dzieciństwo przebiega w izolacji i jest poświęcone głównie pracy na rzecz rodziny.

Diana Gittis (2008) podkreśla, iż „termin «dzieciństwo» posiada znaczenie jedynie $\mathrm{w}$ binarnej relacji $\mathrm{z}$ dorosłością i zawartej $\mathrm{w}$ niej idei o charakterze uniwersalnym" ${ }^{\prime 6}$. Tak postawiona teza dotycząca dzieciństwa może wskazywać również na relacyjny charakter umiejscowienia dziecka w strukturze rodziny, co wydaje się zasadne w odniesieniu do społeczeństw charakteryzujących się silnymi więziami rodzinnymi i tradycyjnie pojmowanymi rolami społecznymi (w kontekście danych uwarunkowań kulturowych). Historie dzieci to historie ich matek $i$ ich rodzin.

\section{Dziecko w islamie}

Pojmowanie istoty dzieciństwa oraz samego dziecka w historycznym ujęciu kontekstu religijnego i wpływu tego kontekstu - islamu, prawa islamu (sharia'h), nauki prawa $\left(f i k h^{\top}\right)$ opartego na szariacie, kultury domu, oraz ich

\footnotetext{
${ }^{5}$ M.J. Kehily, Zrozumieć dzieciństwo: Wprowadzenie w kluczowe tematy i zagadnienia, [w:] Wprowadzenie do badań nad dzieciństwem, red. M.J. Kehily, przekł. ks. M. Kościelniak, Kraków 2008, s. 23.

${ }^{6}$ D. Gittis, Historia konstruktów dzieciństwa, [w:] Tamże, s. 46.

${ }^{7}$ Fiqh, - prawo muzułmańskie (szari'atu) o charakterze religijnym, ale również nauka prawa, część teologii dotycząca życia religijnego, społecznego i państwowego. Podstawą dla figh jest Koran, hadith (haddisy), sunna, kijas i idżma' (Mały słownik kultury świata arabskiego, red. J. Bielawski, Warszawa 1971). Jak podaje Encyklopedia Britannica, Fiqh oznacza w jęz. arabskim „zrozumienie” i w zakresie muzułmańskiego prawodawstwa jest nauką ustalenia dokładnych warunków szariatu, czyli prawa islamskiego, a zbiorowe źródła muzułmańskiego prawodawstwa są określone jako ușūl al-figh. Prawo szariatu pochodzi od Boga i jest niezmienne, ale figh jako "ludzi wysiłek poznania Sharī'ah" może ulegać zmianom i tym samym nie jest doskonały (zob. Figh, [w:] Encyclopaedia Britannica, online, https://www.britannica.com/topic/ fiqh, [dostęp: 08.02.2021]).
} 
wpływu na kształtowanie się dzieciństwa w przypadku wielokulturowego i wieloetnicznego Maroka nie pozwala na postawienie spójnych tez i wywiedzenie jednoznacznych wniosków. Definiowanie dzieciństwa w islamie jest zazwyczaj oparte na zunifikowanej tradycji i tak potraktowanych ramach aksjologicznych. W istocie, w zależności (chociażby) od regionu sama interpretacja prawa koranicznego $\mathrm{w}$ islamie sunnickim jest zróżnicowana i wywodzi się z czterech szkół ewoluujących pomiędzy radykalizacją a modernizacją ${ }^{8}$. Trudno zatem mówić o jednym wspólnym portrecie islamskiego dziecka. W Afryce Zachodniej, i tym samym w Maghrebie, dominuje szkoła Maliki, która oprócz Koranu i Sunny uwzględnia zwyczaj (adat lub urf) i konsensus, zgodę (idżma) oraz dobro powszechne (istislah), a także jest oparta na praktykach mieszkańców Medyny (idżma ahl al madina) ${ }^{9}$, co może warunkować jej bardziej liberalny charakter w stosunku do pozostałych trzech szkól. Prawno-religijna szkoła Maliki wywodzi się od jej założyciela, teologa i prawnika Malika-ibn-Anasa (715-795 n.e.), który opracował Księge równej ścieżki ${ }^{10}$ (Kitab al-Muwatta), jedną z najwcześniej powstałych ksiąg prawnych ${ }^{11}$.

Świat muzułmański sam w sobie jest zróżnicowany. Choć postać Proroka Mahometa, święta księga islamu, Koran, i klasyczny język arabski - język Koranu unifikują społeczeństwo oraz kulturę Bliskiego Wschodu, Maghrebu i Azji, to już praktyki i interpretacja Koranu oraz pochodzenie kulturowe i etniczne poszczególnych nacji zdecydowanie wykazują znaczące różnice. Pierwszą z nich jest podział na islam szyicki i sunnicki, kolejną różnicą są wyodrębnione, poszczególne szkoły prawoznawstwa. Rodzi się więc w tym miejscu pytanie dotyczące deskrypcji konstruktów społecznych w islamie oraz ich natury, w tym wizji dzieciństwa w islamie. Ewa Machut-Mendecka wskazuje na fakt, iż

przez wieki kultura arabsko-muzułmańska zachowała swoją tożsamość, chociaż nie była jednolita i stanowiła wielki konglomerat wzorów, nawet za Umajjadów czy Abbasydów, kiedy stanowiła spójną całość ${ }^{12}$.

Tym samym, mimo zróżnicowania tożsamościowego Marokańczyków, suma codziennych rytuałów rysuje uogólniony model marokańskiej rodziny. Ten dylemat, powiązania deskrypcji rzeczywistości z próbą ujęcia wszelkich tendencji determinowanych przez islam na danym terytorium, wydaje się najtrudniejszy do rozstrzygnięcia i tym samym wymusza traktowanie religii

${ }^{8}$ A. Asadulla, Islam Vs. West: Fact or Fiction? A brief historical, political, theological, philosophical and psychological perspective, Bloomington 2008, s. 30.

9 J. Danecki, Podstawowe wiadomości o islamie, Warszawa 2007, s. 213-214.

${ }^{10}$ Janusz Danecki tłumaczy termin Al - Muwatta jako Udeptana ścieżka. (zob. tamże, s. 214).

${ }_{11}$ Malik ibn Anas, [w:] Maty stownik kultury świata arabskiego, s. 327.

${ }^{12}$ E. Machut-Mendecka, Świat tradycji arabskiej, Warszawa 2005, s. 133. 
jako mimo wszystko jakości ewoluującej i różnicującej. Dodatkową trudność powodują bardzo nieliczne źródła mówiące o istocie pojmowania dzieciństwa w islamie. Odnoszą się one raczej do założeń ogólnych; niż są poświęcone analizom dotyczącym poszczególnych regionów czy krajów świata islamu, niekoniecznie krajów arabskich. Dzieci arabskie są charakteryzowane jako te żyjące zgodnie ze wzorami wychowania preferowanymi przez ich kolektywne, patriarchalne rodziny $w$ świecie tradycji beduińskiej, arabskiej i od XIX stulecia w zderzeniu z globalizacją ${ }^{13}$. Ten ostatni czynnik wpływa na zdecydowaną akcelerację zmian zarówno odnoszących się do systemu wartości, jak i relacji interpersonalnych.

Islam (...) plemiennemu kolektywizmowi przeciwstawił indywidualizm (...), starał się wyzwolić jednostkę spod bezwzględnej hegemonii wspólnoty (...), zgodnie z Koranem wszyscy ludzie są równi, nie wyłączając kobiet i mężczyzn. (...) Niemniej jednak patriarchat nie upadł $\mathrm{z}$ dnia na dzień, islam kontynuował tradycję judeochrześcijańską (...). Znalazł swój wyraz w treściach Koranu, ich odbiciem jest też prawo zwyczajowe - urf - i kultura ludowa ${ }^{14}$.

Do dziś pozycja kobiety w społeczeństwie muzułmańskim, jej prawa i obowiązki są sprawą dyskusyjną, tak samo jak wychowanie dzieci. W Maroku natomiast wiele rodzin Amazigh kultywuje tradycje i obyczaje plemienne pochodzące sprzed VII wieku, sprzed okresu najazdu Arabów na obszary Afryki Północnej, co znacząco wpływa na traktowanie kobiet i styl wychowania potomstwa.

Maroko na mapie krajów muzułmańskich jest przypadkiem szczególnym jeszcze $z$ innego powodu. Marokańczyk Tahar Ben Jelloun ${ }^{15}$ wskazuje na jego dwoistość, mieszczącą się pomiędzy tradycją a nowoczesnością. Znajduje to wyraz w społecznym uznaniu egalitarnego statusu kobiet, które z jednej strony walczą o swoje prawa, a z drugiej „bronią dyskursu fundamentalistów islamskich i dobrze się w nim odnajdują", wspierając między innymi jego perswazyjny wymiar $^{16}$. Zapewne wiele czynników wpływa na tak zachowawcze postawy kobiet $w$ nadal warunkowanym silnie przez tradycję społeczeństwie. Jeszcze w 1972 roku Driss Chraïbi ${ }^{17}$ w swojej książce La Civilisation,

${ }^{13}$ Zob. E. Machut-Mendecka, Być dzieckiem arabskim, [w:] Dziecko w oriencie, red. D. Chmielowska, B. Grabowska, E. Machut-Mendecka, Warszawa 2013, s. 57-58.

${ }^{14}$ Tamże, s. 59-60.

${ }_{15}$ Tahar Ben Jelloun, ur. 01.12.1947 r. w Fezie (Maroko) - jeden z najwybitniejszych współczesnych pisarzy, nowelistów pochodzenia marokańskiego tworzących po francusku. Obecnie mieszka w Paryżu.

16 T. Ben Jelloun, Co to jest islam?, Kraków 2018, s. 209-210.

17 Driss Chraïbi, ur. 15.07.1926 r. w El Jadida (Maroko), zm. 01.04. 2007 r. w Drôme we Francji - nowelista pochodzenia marokańskiego piszący po francusku. W swojej twórczości podejmował tematy o charakterze autobiograficznym, związane z kolonializmem, zderzeniem cywilizacji arabskiej i zachodniej (francuskiej), imigracją, depresją, czy sytuacją kobiet (zob. m.in. CBC Arts, 
ma Mére!... (wyd. polskie - Przebudź się, matko! = z 2007 r.) następująco portretował marokańską kobietę i matkę:

Jej życie było jak układanka. Swój świat wewnętrzny próbowała dopasować do życia w społeczeństwie, które bezwzględnie wymagało od niej wypełniania roli matki i żony. Bez trudu przyswajała wszystko, co było na miarę jej możliwości, co mogła poczuć, zobaczyć, usłyszeć, posmakować i pokochać. Odrzucała natomiast wszystko to, co w otaczającym świecie zakłócało jej wrażliwość. (...) Rytm jej życia był powolny, bardzo powolny, bo był to rytm natury. Wszelkie przyśpieszenie życia lub historii kazało jej się wycofać, choć często wiele spraw bezpośrednio jej nie dotyczyło, nie była im podporządkowana, ponieważ nie była w nie wliczona. Dorastanie dzieci, zetknięcie z nowymi zdobyczami cywilizacji czy jakieś nieoczekiwane zdarzenie w jej otoczeniu, to było to, co dotyczyło jej świata w sposób bezpośredni i umiała sobie z tym poradzić $(\ldots)^{18}$.

Tahar Ben Jelloun kończy swój wywód stwierdzeniem, iż „Maroko zawsze było krajem umiaru", postulując zdecydowanie rozdział sfery publicznej od prywatnej, gdyż

w przeciwnym wypadku przekażemy naszym dzieciom złe nawyki i zamkniemy je w patologicznym i zacofanym, mrocznym i pogmatwanym świecie, gdzie jedyne drzwi będą prowadzić do przemocy ${ }^{19}$.

Przeświadczenie, że brak narzędzi społecznych i niewydolność samych rodzin skazuje wiele dzieci w Maroku na życie na ulicy znajdzie swoje potwierdzenie w dalszej części tekstu.

\section{Marokańska rodzina}

Badacz izraelski Avner Gil'adi w pracy Children of Islam: concepts of childhood in medieval Muslim society z 1992 roku (Dzieci Islamu: koncepcja dzieciństwa w średniowiecznym społeczeństwie muzutmańskim) rekonstruuje postawę wobec dziecka $w$ islamie okresu średniowiecza jako generalnie ambiwalentną, jednak zdecydowanie faworyzującą płeć męską. Jak podaje dalej Hugh Cunningham, recenzując książkę Gil'adi'ego:

Islam zarówno zachęcał rodziców, by cenili dzieci, a jednocześnie odradzał nadmierną miłość. (...) Dzieciństwo zostało uznane za odrębny stan w średniowiecznym islamie $\mathrm{i}$ było postrzegane jako ważne $\mathrm{w}$ formowaniu życia dorosłego ${ }^{20}$.

Moroccan-French novelist Driss Chraibi dies, 02.04 .2007 r. online; https:/ / www.cbc.ca/news/entertainment/moroccan-french-novelist-driss-chraibi-dies-1.665040, [dostęp: 08.02.2021].)

${ }_{18}$ D. Chraïbi, Obudź się matko!, przekł. M. Cywińska, R. Abou-Hilal, Warszawa 2007, s. 41.

19 T. Ben Jelloun, Co to jest islam?, s. 212.

${ }^{20} \mathrm{H}$. Cunningham, Avner Gil'adi: Children of Islam: concepts of childhood in medieval Muslim society. (St Antony's/Macmillan Series.) xii, 176 pp. Basingstoke and London: Macmillan Ac- 
E. Machut-Mendecka wskazuje natomiast, że to właśnie islam, w przeciwieństwie do wcześniejszej tradycji okresu ciemności i niewiedzy - dżahilijji na Bliskim Wschodzie, zakazał okrutnych praktyk zabijania dziewczynek oraz nakazał rodzicom, a zwłaszcza ojcom, „starannie wychowywać cór$\mathrm{ki}$, dawać im wykształcenie nie gorsze niż własne" ${ }^{21}$. Ojciec w patriarchalnej strukturze zapewnia byt, opiekuje się rodziną, niekiedy przekształcając opiekę we władanie, jednak to pozycja kobiety jako matki młodego muzułmanina jest wysoka, a macierzyństwo stanowi w islamie niepodważalną wartość22.

Jeszcze na początku XX wieku, w czasach protektoratu francuskiego, marokańska tradycyjna patriarchalna rodzina funkcjonowała często $\mathrm{w}$ formie rodzinnego haremu. Taka wizja rodziny została przedstawiona w książce Fatimy Mernissi ${ }^{23}$ zatytułowanej Dzieciństwo w haremie. Sny o wolności. Autorka, socjolożka, pisarka i przede wszystkim feministka, poświęciła tę pracę kobietom, kreśląc jednocześnie studium marokańskiej kultury i społeczeństwa, a prowadząc narrację z pozycji dziecka - również dzieciństwa, które, jak pisze, było mimo wyznaczonych granic - hudud ${ }^{24}$, szczęśliwe. Autorka książki jako jej narratorka $\mathrm{w}$ rozmowie $\mathrm{z}$ kuzynem Samirem rozważa istotę haremu jako miejsca, idei hudud oraz prawdy. „Edukacja to znajomość hudud, świętych granic. (...) Dla dziecka respektowanie hudud to bycie posłusznym"25. Wychowanie było więc stawianiem sztywnych granic, a powinnością dziecka ich respektowanie.

W literaturze marokańskiej przedstawione są też opisy dzieciństwa przeżywanego w okresie kolonialnym Maroka - pełne cierpienia, zmagań z codziennością i walki o przetrwanie w dosłownym znaczeniu. Przykładem li-

ademic and Professional Ltd., 1992, Bulletin of the School of Oriental and African Studies, February 1994, 57, 1, s. 232-233; https:/ / doi.org/10.1017/S0041977X00028305,online,Cambridge University Press: 05 February 2009.

${ }^{21}$ E. Machut-Mendecka, Być dzieckiem, s. 59.

${ }^{22}$ Tamże, s. 62.

${ }^{23}$ Fatima Mernissi, ur. 27.09.1940 r., zm. 30.11. 2015 r. - socjolożka, pisarka i marokańska feministka ,jest uważana za jedną z głównych postaci myśli feministycznej zarówno w Maroku, jak i ogólnie w społeczeństwie muzułmańskim", jej twórczość literacka portretuje głównie kulturę Maroka w okresie kolonializmu, rolę i miejsce kobiety w społeczeństwie marokańskim, granice między sferą prywatną a publiczną, między tradycją a modernizmem, zob. m.in. R. Rhouni, Secular and Islamic Feminist Critiques in the Work of Fatima Mernissi, Series: Women and Gender: The Middle East and the Islamic World, 2009, 9; https://brill.com/view/title/15825, [dostęp: 02.02.2021].

${ }^{24}$ Termin arabski hudud (1. poj. hadd) znaczy dosłownie "granice" (ang. boundries, limits), w islamskim prawodawstwie karnym oznacza "z góry ustalone kary” za czyny wymienione w Koranie jako zabronione dla muzułmanina, np.: rozpusta, cudzołóstwo, konsumpcja alkoholu, czy kradzież; zob. A. Fraser Fujinga, Islamic Law in Post-Revolutionary Iran, [w:] The Oxford Handbook of Islamic Law, red. M.E. Anver, A. Rumee, Oxford 2018, s. 618.

${ }^{25}$ F. Mernissi, Dzieciństwo w haremie. Sny o wolności, przekł. E. Skweres, Warszawa 2001, s. 11. 
teratury tego typu jest autobiograficzna proza Muhammada Szukri ${ }^{26} \mathrm{Al}-\mathrm{khobz}$ Al-Hafi (fr. Le Pain nu), obnażająca codzienność życia dziecka z najuboższej, licznej, dysfunkcyjnej rodziny z brutalnym ojcem, które podejmuje się każdej pracy, by przeżyć w najcięższych warunkach, wśród wykluczonych i wyrzuconych poza nawias społeczeństwa. Los wynagradza Szukri jego determinację i w finale zostaje pisarzem, jednak wiele marokańskich dziecięcych biografii nawet i współcześnie naznaczonych jest w ten - rzutujący na całe życie - sposób. Negatywne zjawiska, które w innych społeczeństwach są zaledwie incydentalne lub marginalne, w społeczeństwie marokańskim są nadal silnie obecne.

Współcześnie, w opinii Paoli Gandolfi, rodziny Maghrebu podlegają przeobrażeniom - od tradycyjnego modelu „rodziny arabskiej” oraz „społeczeństwa islamskiego” do (jak sama badaczka podkreśla) „rodzin całkiem dalekich od tych modeli" ${ }^{27}$. Indywidualne trajektorie rozwoju marokańskiej rodziny, warunkowane kulturowo, ale i poddane siłom postępu, różnicują te modele W stronę rodziny nuklearnej ${ }^{28}$. Tradycyjnie rodzina jest „podstawową instytucją społeczną w marokańskim społeczeństwie”, stanowi także nośnik tradycji i miejsce troski oraz opieki nad jej członkami ${ }^{29}$, jak też „podstawową instytucję porządku społecznego" (institution de base de l'ordre social), która w czasach kryzysu powinna być gwarantem wartości, głównie solidarności ${ }^{30}$.

Modele marokańskiej rodziny są obecnie wynikiem wielowiekowego dążenia do postępu w stylu zachodnim i walki o równouprawnienie. Jak dodaje Gandolfi, zmianie uległa głównie struktura rodziny i relacje pomiędzy poszczególnymi jej członkami na tle ewoluującego systemu wartości, stopnia partycypacji ze względu na płeć i urbanizacji widocznej głównie w miastach ${ }^{31}$.

Naczelnym hasłem w Maroku jest „modernizacja” - obecna w każdym obszarze życia. W tym kraju

większość dyskursów politycznych, a także dyskursów w mediach i społeczeństwie obywatelskim opiera się na idei „postępu” wraz z ideami demokratyzacji, równości, edukacji i dobrego zarządzania ${ }^{32}$.

${ }^{26}$ Zob. E. Machut-Mendecka, Być dzieckiem, s. 72.

${ }_{27}$ P. Gandolfi, Multiple families in changing societies in the Maghreb: The case of Morocco, DIFI Family Research and Proceedings, 2015, 7; http://dx.doi.org/10.5339/ difi.2015.7, s. 1.

${ }^{28}$ E. Machud-Mendecka, Być dzieckiem, s. 77.

${ }^{29}$ Morocco. Situation of Unaccompanied Minors. Report 2/2017, Report based on interviews in Morocco, 9 to 18 October 2016, Copenhagen 2017, s. 10.

${ }^{30}$ Démographie: famille au maroc: les réseaux de la solidarité familiale, Famille au Maroc: les réseaux de la solidarité familiale. Avant-propos, 16/03/2011, Haut-Commissariat au Plan du Maroc, Centre National de Documentation, 2011. s.2. https:/ / www.hcp.ma/downloads/Demographie-Famille-au-Maroc-les-reseaux-de-la-solidarite-familiale_t13086.html, [dostęp: 29.11.2019].

31 P. Gandolfi, Multiple families in changing societies, s. 1.

32 Tamże. 
W popierającym drogę reform modernizacyjnych dyskursie władcy Maroka, króla Muhammada VI, postęp jest utożsamiany między innymi ze społeczeństwem obywatelskim, rozumianym przez pryzmat „odpowiedzialnego

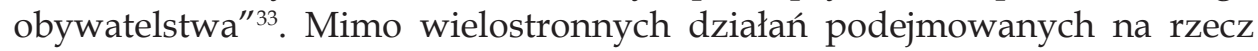
owego postępu, dysproporcje, przede wszystkim ekonomiczne, ale też kulturowe, pomiędzy marokańską wsią a miastem nadal wydają się znaczące.

Raport opracowany przez marokański Wysoki Komisariat ds. Planowania, zatytułowany Société, famille, femmes et jeunes, 50 ans de développement humain et perspectives (Społeczeństwo, rodzina, kobiety i młodzież, 50 lat rozwoju człowieka i perspektywy), zwraca uwagę na wartości solidarności, które były tradycyjnie obecne w marokańskim społeczeństwie i marokańskiej rodzinie:

Społeczeństwo marokańskie doświadczyło tradycyjnych form solidarności społecznej, zbiorowej lub rodzinnej, które funkcjonowały jako mechanizmy samopomocy i łagodzenia napięć społecznych. To solidarność istniała na poziomie rodziny poprzez wsparcie dla członków rodziny, wsparcie ze strony rodziny dla osób starszych, rozwiedzionych kobiet lub wdów i rodziców bez zasobów materialnych. Rodzina zapewniła wszystkie funkcje dla jednostki: edukacyjną, ekonomiczną i opiekę w przypadku chorób ${ }^{34}$.

Taki model rodziny obowiązuje w społeczeństwach, w których relacje międzyludzkie przeważają nad relacjami instytucjonalnymi, jak ma to miejsce w kulturach świata zachodniego ${ }^{35}$. Według $97 \%$ respondentów biorących udział $\mathrm{w}$ badaniach przeprowadzonych na potrzeby raportu dotyczącego wartości kultywowanych w społeczeństwie marokańskim, przygotowanego przez zespół pod kierunkiem Hassana Rachika, dziecko jest zobowiązane do opieki nad rodzicami w momencie osiągnięcia przez nich starości. Tylko $2 \%$ badanych wskazało instytucje państwowe i organizacje pozarządowe jako te, które mogą "konkurować z rodziną” w tym zakresie ${ }^{36}$. Wydaje się więc, że niezależnie od kultury domu rodzinnego - zgodnej z kulturą dominującą lub nie - życie marokańskiego dziecka naznaczone jest świadomością konieczności partycypowania w opiece nad rodzicami i ponoszenia wszelkich kosztów z nią związanych, niezależnie od własnego statusu rodzinnego czy materialnego w przyszłości. Jednocześnie, zamieszczona w 2012 roku na stronach „L'Economiste” analiza modelu współczesnej marokańskiej rodziny wskazu-

33 Tamże.

${ }^{34}$ R. Bourqia i in., Société, famille, femmes et jeunes, 50 ans de développement humain et perspectives, Cinquantenaire de l'Indépendance du Royaume du Maroc, 2005/2614, Royaume du Maroc, s. 25.

${ }^{35} \mathrm{H}$. Rachik i in., Rapport de synthèse de l'enquête nationale sur les valeurs, 50 ans de développement humain et perspectives, Cinquantenaire de l'Indépendance du Royaume du Maroc, 2004, 2005/2602, Royaume du Maroc, s. 18.

${ }^{36}$ Tamże. 
je na ewolucję w stronę mniejszej dzietności. Wzrasta też liczba chorób przewlekłych w rodzinach ${ }^{37}$. Tym samym, konieczność opieki nad starzejącymi się rodzicami dotyczy coraz mniejszej liczby dzieci w rodzinach, coraz bardziej je obciążając. Kolejnymi istotnymi czynnikami wpływającym na funkcjonowanie marokańskiej rodziny są jej rozpad i coraz liczniejsze rozwody. Zdaniem Yasminy El Fethouni i Nicolasa Hamelina, to właśnie rozwody są jedną z najczęściej obserwowanych zmian we współczesnym społeczeństwie marokańskim. Autorzy, powołując się na opracowanie Shikhaniego z 2010 roku, wskazują, że wzrost ten nastąpił aż o $13 \%{ }^{38}$.

\section{Kodeks rodzinny}

Lustrem zmian dotyczących kierunku modernizacji marokańskiej rodziny, systemu wartości, zabezpieczenia praw kobiet i dzieci jest tamtejszy kodeks rodzinny, potocznie zwany Mudawwana (w jęz. arabskim Mudawwanat al-Usra al-Maghribiyya), wypracowany po raz pierwszy przez Salafitów w 1958 roku, dwa lata po uzyskaniu niepodległości przez Maroko. Z pewnością do dziś kodeks ten pozostałby w niezmienionej wersji, a uwarunkowania społeczno-religijne dla marokańskiego dzieciństwa byłyby inne, gdyby nie walka marokańskich kobiet zrzeszonych w ruchach feministycznych o bardziej liberalne prawa dla siebie i rodziny ${ }^{39}$. Według marokańskiej badaczki literatury, języka i feminizmu Fatimy Sadiqi, ruch feministyczny w Maroku zapoczątkowało Stowarzyszenie Sióstr Czystości, żądając w 1946 roku zniesienia poligamii, pełnych i równych praw politycznych oraz wzrostu widoczności kobiet w sferze publicznej. Uchwalony w 1957 roku kodeks Mudawwana nie spełniał oczekiwań kobiet, gdyż podstawą jego stworzenia było islamskie orzecznictwo szkoły Maliki, choć kodeks karny, jak i konstytucja powstały wówczas na podstawie prawa cywilnego ${ }^{40}$. W ciągu kolejnych lat, pod naciskiem wspomnianych ruchów feministycznych, kodeks rodzinny przechodził kolejne modyfikacje. W 1999 roku na tron wstąpił król Muhammad VI

37 Analyse. Ces nouveaux profils de la famille marocaine: Moins d'enfants, plus de maladies chroniques, L'Economiste, Edition No:3756 Le 05/04/2012, online; https:/ /www.leconomiste.com/ article/893043-ces-nouveaux-profils-de-la-famille-marocaine-moins-d-enfants-plus-de-maladies-chroniq, [dostęp: 29.11.2019].

38 Y. El Fethouni, N. Hamelin, The Effect of Media and Economics on The Change of Divorce rate in Morocco, International Journal of Academic Research and Reflection, 2016, 4, 3. online, s. 20; https://www.idpublications.org/wp-content/uploads/2016/03/Full-Paper-THEEFFECT-OF-MEDIA-AND-ECONOMICS-ON-THE-CHANGE-OF-DIVORCERATE-IN-MOROCCO.pdf, [dostęp: 10.02.2021].

39 P. Gandolfi, Multiple families in changing societies, s. 2.

40 F. Sadiqi, Morocco, [w:] S. Kelly, J. Breslin, Women's Rights in the Middle East and North Africa: Progress Amid Resistance, New York 2010, s. 311. 
i dwa lata później utworzył komisję mającą zreformować kodeks. Ostateczny kształt dokumentu został zatwierdzony w 2003 roku i wprowadzony w życie 3 lutego 2004 roku $^{41}$. Zmiany zawarte w kodeksie dotyczyły

(...) prawa do samoopieki, prawa do rozwodu i prawa do opieki nad dzieckiem. [Kodeks - E.J.] nałożył też nowe ograniczenia dotyczące poligamii, podniósł legalny wiek małżeństwa z 15 do 18 roku życia oraz zakwalifikował molestowanie seksualne jako podlegające karze prawnej. Nie zniesiono jednak całkowicie poligamii, jednostronnego odrzucenia żony przez męża, rozwodu, separacji przez kompensatę (khula) $)^{42}$ lub dyskryminacji w regułach dziedziczenia ${ }^{43}$.

\section{Sadiqi dodaje również, iż}

kobiety mają teraz więcej swobody w podróżowaniu, w uzyskaniu zatrudnienia, w podejmowaniu edukacji, [doświadczają - E.J.] większej równości w domu i większej swobody negocjacji swoich praw małżeńskich. Są liderkami przedsięwzięć biznesowych i awansują na wyższe szczeble edukacji. Istotny postęp również dokonał się w obszarze ochrony kobiet przed przemocą domową oraz w kwestii ich wsparcia ${ }^{44}$.

Mudawwana wpłynęła więc również pośrednio na losy marokańskich dzieci, gwarantując lepsze warunki funkcjonowania społecznego ich matkom w strukturze rodziny oraz na rynku pracy.

\section{Dziecięce małżeństwa}

Jak już wspomniano, nowelizacja kodeksu rodzinnego Mudawwana polegała między innymi na podwyższeniu wieku legalnego zawarcia małżeństwa z 15 do 18 roku życia. Mimo wprowadzenia powyższych zabezpieczeń legislacyjnych, liczba małżeństw nieletnich w Maroku wzrasta i najdotkliwsze konsekwencje tego trendu ponoszą dziewczęta. Jak podają oficjalne raporty ${ }^{45}$, do-

${ }^{41}$ Zob. tamże oraz Mudawwanat al-Usra al-Maghribiyya-Wizarat al-'Adl wa al-HurriyatAl-Mumlaka Al-Maghribiyya/Code de la Famille-Ministe`re de la Justice et des Libertes-Royaume du Maroc-Dahir n. 1-04-22 du 12 Hija 1424 (3 Fevrier 2004) portant promulgation de la Loi n. 7003 portant Code de la Famille.

${ }^{42} K h u l a, K h u l '$ - jest to jedna $\mathrm{z}$ form rozwodu wśród akceptowanych $\mathrm{w}$ islamskim prawodawstwie, która polega na zgodzie męża na rozwód w zamian za kompensatę, zazwyczaj finansową, ze strony żony. Istnieją znaczące różnice pomiędzy rozumieniem $k h u l ' w$ interpretacji jurysprudencji szkoły Hanafi (np. w Egipcie) a interpretacji według jurysprudencji szkoły Maliki w Maroku; szerzej zob. N. Sonneveld, Divorce Reform in Egypt and Morocco: Men and Women Navigating Rights and Duties, Islamic Law and Society, 2019, 26, s. 149-178.

${ }_{43}$ F. Sadiqi, Morocco, s. 312-313.

${ }^{4}$ Tamże, s. 3-4.

45 Raport UNICEF na podstawie danych Ministerstwa Sprawiedliwości i Wolności Maroka za lata 2004-2014 wskazuje, że liczba małżeństw nieletnich w stosunku do wszystkich małżeństw zawieranych przed sądami rodzinnymi przez 9 lat wzrosła z 7,0\% w 2004 roku do 11,5\% 
niesienia medialne ${ }^{46}$, jak i publikacje organizacji pozarządowych, nadal tysiące dziewcząt już od 13 roku życia zawiera związki małżeńskie ${ }^{47}$. Sędziowie wydający zgody na małżeństwa nieletnich korzystają z luki prawnej w kodeksie rodzinnym, stanowiącej, że małżeństwo nieletnich może być zalegalizowane ze względu na pewne skłaniające ku takiej decyzji okoliczności. Niestety, takie rozwiązania stają się regułą ${ }^{48}$ około $92 \%$ aplikacji w sprawie uznania małżeństwa jest zatwierdzanych pozytywnie, co nie może być akceptowane i budzi sprzeciw oraz oburzenie stowarzyszeń feministycznych ${ }^{49}$. Takie działania nie tylko podtrzymują stan faktyczny liczby małżeństw nieletnich sprzed nowelizacji Mudawwany, a nawet wpływają na jej wzrost. Ponadto, wiele małżeństw religijnych pozostaje niezarejestrowanych. Zjawisko to występuje zarówno w rodzinach dobrze sytuowanych, jak i ubogich, ze środowisk wiejskich, między innymi tych migrujących do miast. Wśród różnych przyczyn tej sytuacji, przede wszystkim warunkowanych tradycją, uzależnieniami religijnymi, występują także: ubóstwo całej rodziny oraz brak realizacji obowiązku szkolnego przez dzieci. Małżeństwo nieletnich stanowi w tradycyjnym rozumieniu zabezpieczenie przed pozamałżeńską aktywnością seksualną i nastoletnim pozamałżeńskim macierzyństwem plamiącym honor rodziny ${ }^{50}$.

\section{Dzieci bez statusu, dzieci bez rodziny - porzucone lub osierocone}

W marokańskiej rzeczywistości dzieci, które przyszły na świat w związkach pozamałżeńskich lub których ojciec jest nieobecny znajdują się na marginesie społeczeństwa. Bez procedury legitymizacji nie mają szans na opiekę

w 2013 roku; zob. Morocco - Regional Study on Child Marriage, UNICEF, s. 6-7, online; https:/ / www.unicef.org/morocco/media/181/file/Mariage\%20des\%20enfants\%20au\%20Maroc.pdf, [dostęp: 10.02.2021].

${ }^{46}$ Zob.m.in.:A.BenSaga,Study:ChildMarriagesinMoroccoAreIncreasing,09.01.2019r.,Morocco WorldNews, online;https:// www.moroccoworldnews.com/2019/01/262828/study-child-marriages-in-morocco-are-increasing/, [dostęp: 10.02.2021]; Z. Abdennebi, Morocco struggles to curb rise in number of girls married underage, 26.04 .2018 r., Reuters, online, https:/ / www.reuters.com /article/us-morocco-women-idUSKBN1HX22T, [dostęp: 10.02.2021].

${ }^{47}$ Część danych dotyczy ogólnie małoletnich poniżej 18 roku życia.

48 2017-22: Child Marriages In Morocco, NGO KVINFO Denmark and Droit \& Justice (D\&J) Morocco, online, https://kvinfo.dk/mena/projects/2017-22-child-marriages-in-morocco/?lang=en, [dostęp: 28.11.2019].

49 A. Naqrachi, Early Marriage in Morocco, [w:] A New Paradigm: Perspectives on the Changing Mediterranean, red. S. Toperich, A. Mullins, Center for Transatlantic Relations SAIS, July 14, 2014, s. 219.

50 2017-22: Child Marriages In Morocco; Report: Morocco: Marriage and divorce legal and cultural aspects, The Norwegian Country of Origin Information Centre Landinfo, 21.04. 2017, s. 27, online; https://landinfo.no/wp-content/uploads/2018/04/Morocco-Marriage-and-divorcelegal-and-cultural-aspects-21042017-final.pdf, [dostęp: 10.02.2021]. 
zdrowotną, edukację, czy w późniejszym okresie życia na podjęcie legalnej pracy. Ich matki dotyka społeczny ostracyzm. Katherine E. Hoffman w obszernym i dokładnym opracowaniu dotyczącym statusu prawnego i zwyczajowego marokańskich dzieci wychowywanych w rodzinach, jak i tych nieusynowionych wskazuje, że

Kodeks rodzinny [Mudawwana - E.J.] nie reguluje statusu prawnego ani praw dzieci nieusynowiony $\mathrm{ch}^{51}$; jego art. 149 stanowi, że "przysposobienie nie ma żadnej wartości prawnej" i nie pociąga za sobą praw wynikających z synostwa. Rozwiązania prawne dotyczące dzieci obejmują art. 32 i 34 Konstytucji marokańskiej z 2011 r. zawierającej ogólne zasady dotyczące praw wszystkich dzieci, „niezależnie od statusu rodzinnego". Ustawa z 2002 r. odnosząca się w szczególności do kafala ${ }^{52}$ (opieki islamskiej) reguluje opiekę prawną z władzą rodzicielską nad dziećmi bez rodziców, jako umowę między Prokuratorem królewskim prowincji a osobami prywatnymi ${ }^{53}$.

Jak pisze dalej autorka,

Nie ulega wątpliwości, że „legalna” rodzina małżeńska znajduje się w centrum marokańskiego społeczeństwa, co zostało stwierdzone w Konstytucji w art. 32. Dzieci spoza tego kontekstu nadal cierpią na skutek napiętnowania i wykluczenia społecznego ${ }^{54}$.

Najnowsze oficjalne dane statystyczne dotyczące dzieci bez rejestracji ich ojca wskazują, że jest ich w Maroku około 210000 i najlepsze rozwiązanie dla ich przyszłości stanowi regulowana marokańskim prawem opieka islamska

${ }^{51} \mathrm{~W}$ tekście $\mathrm{w}$ języku angielskim opisano takie dzieci jako children without filiation, co można tłumaczyć jako bez ojca, nieusynowione, bez pochodzenia (ancestry).

${ }_{52}$ Arabska kafāla "to forma ochrony dzieci, która istnieje w kilku krajach, których systemy prawne są oparte na prawie muzułmańskim lub na nim inspirowane i która zabrania adopcji dzieci. W muzułmańskim systemie prawnym kafala jest rodzajem delegacji władzy rodzicielskiej, na mocy której kafil (dorosły) zgadza się wspierać makfoul (dziecko), dopóki on/ ona nie stanie się pełnoletni/a, poprzez zaspokajanie wszystkich jego podstawowych potrzeb (jedzenie, odzież, edukacja). W niektórych krajach, takich jak Maroko [według jurysprudencji szkoły Maliki - E.J.], istnieją dwa rodzaje kafali: sędzia wydaje sądową kafalę, która dotyczy tylko porzuconych dzieci umieszczonych na stałe $\mathrm{w}$ domu dziecka (dziecko może mieć znane lub nieznane pochodzenie). Certyfikowana notarialnie kafala jest przeznaczona dla dzieci, których rodowód jest znany. Notariusz potwierdza akt za zgodą rodziców. W niektórych sytuacjach wiąże się to z przekazaniem władzy rodzicielskiej. Przekazanie może być dobrowolne przez rodzica (np. krewnemu, np. cioci lub wujowi) lub odbywa się w celu ochrony dziecka, które zostało porzucone przez rodziców", Kafala, Komisja Europejska, AD HOC QUERY ON 2019.88 Kafala children, Requested by EMN NCP Spain on 4 October 2019, Responses from Austria, Belgium, Croatia, Cyprus, Czech Republic, Estonia, Finland, Germany, Hungary, Ireland, Italy, Latvia, Lithuania, Luxembourg, Malta, Netherlands, Poland, Slovakia, Spain, Sweden, United Kingdom plus Norway (22 in Total), online, s. 1-2; https:/ /ec.europa.eu/ home-affairs/sites/homeaffairs/files/201988_kafala_children.pdf, [dostęp: 10.02.2021].

${ }^{53}$ K.E. Hoffman, Morocco, [w:] Filiation and the Protection of Parentless Children, red. N. Yassari, L.M. Möller, M.C. Najm, The Hague 2019, s. 232.

${ }^{54}$ Tamże, s. 233. 
kafala. Może ona odbyć się zarówno w formie $k a f a l i^{55}$ kontraktowanej w sądzie rodzinnym, jak i kafali zawieranej w obecności notariusza ${ }^{56}$. Na terenie Maroka wprowadzane są również dla dzieci rozwiązania instytucjonalne $\mathrm{w}$ formie placówek opiekuńczych, pełniących paradoksalnie nierzadko rolę miejsca, gdzie dzieci z rodzin o niskich dochodach są umieszczane przez własnych krewnych w celu poprawienia sytuacji bieżącej, ale również możliwości lepszego funkcjonowania w przyszłości ${ }^{57}$.

\section{Dzieci-migranci, dzieci ulicy}

Terytorium Maroka jest szlakiem tranzytowym do Europy, którym przemieszczają się zarówno Marokańczycy, jak i mieszkańcy innych krajów Afryki. Do Maroka i Europy trafiają zarówno dzieci z rodzinami, jak i dzieci pozbawione opieki dorosłych, opisywane w międzynarodowych raportach jako „unaccompanied”. Raport duńskiego Ministerstwa Imigracji i Integracji z 2017 roku wskazuje na czynniki ekonomiczne, poczucie braku praw politycznych i przemoc w rodzinach jako przyczyny decydujące o podjęciu przez marokańską młodzież decyzji o emigracji ${ }^{58}$. Szwajcarska organizacja pozarządowa Humanium w 2013 roku podawała, za Marokańskim Ministerstwem Solidarności, Kobiet, Rodziny i Rozwoju Społecznego, że oficjalnie na ulicach miast żyło wówczas od 10000 do 30000 dzieci (w tym w największym mieście Maroka - Casablance). Przedstawione liczby są orientacyjne; ze względu na migrację funkcjonującą wewnątrz Maroka - pomiędzy miastami, ze wsi do miast, jak i tę z Maroka do innych państw. Rzeczywiste dane mogą być dużo wyższe. Dzieci żyjące na ulicach to zarówno dzieci pracujące w dzień w sektorze drobnych, podstawowych usług, na przykład sprzedaży dla przechodniów, i wracające na noc do domu, jak i te, które całe swoje życie spędzają w niestabilnej sytuacji życia na ulicy, poza obowiązkiem szkolnym, narażone na wszystkie rodzaje handlu, kontakt z dziecięcą prostytucją i pedofilią, narkotykami i przemocą, odurzające się najtańszymi substancjami halucynogennymi, by zapomnieć o swojej sytuacji ${ }^{59}$. Dzieci podejmujące próbę emigracji do Europy, również i tam napotykają sytuacje niesprzyjające stabilizacji i bezpieczeństwu życia. Są wśród nich też takie, które trafiają do ośrodków dla uchodźców, migrantów i innych instytucji opieki prowadzonych przez rząd lub organizacje pozarządowe $\mathrm{w}$ danym kraju docelowym.

${ }_{55}$ Tamże, s. 245.

56 Tamże, s. 247.

${ }^{57}$ Morocco. Situation of Unaccompanied Minors, s. 6.

${ }^{58}$ Tamże.

59 Street children of Morocco, NGO Humanium; https://www.humanium.org/en/ street-children-of-morocco-2/ [dostęp: 29.11.2019]. 


\section{Praca marokańskich dzieci}

Roczny raport krajowy UNICEF z 2017 roku wskazuje na rosnącą świadomość społeczną opinii publicznej na temat sytuacji dzieci w Maroku. Przeprowadzone na jego terenie badania odnośnie sytuacji dzieci dowiodły, że 4 na 10 dzieci żyło w ubóstwie, a pośród nich 3 zamieszkiwało obszary wiejskie ${ }^{60}$. To często skrajny niedostatek powoduje, że dzieci zmuszone są do podjęcia pracy zarobkowej już od najwcześniejszych lat, narażając się na niebezpieczeństwo. Badania zrealizowane przez Wysoki Komisariat ds. Planowania (Haut Commissariat au Plan) Królestwa Maroka, dotyczące zatrudnienia w 2017 roku, wskazują, że z grupy około 7049000 dzieci w wieku od 7 do 17 lat, 247000 podejmuje pracę fizyczną, a 162000 wykonuje prace niebezpieczne. Dzieci zamieszkujące wieś stanowią w tej grupie aż $76,3 \%$ i są to głównie chłopcy. 10,6\% dzieci wykonujących prace niebezpieczne realizuje obowiązek szkolny, ale aż 81,4\% dzieci opuściło szkołę. $8 \%$ dzieci nigdy nie realizowało obowiązku szkolnego z różnych przyczyn. Prace niebezpieczne w rolnictwie, leśnictwie i rybołówstwie wykonuje 82,6\% dzieci, głównie zamieszkałych na terenach wiejskich, w sektorze usług pracuje $52,7 \%$ oraz prace $\mathrm{w}$ przemyśle i rzemiośle podejmuje $32 \%{ }^{61}$. Dziewczęta pracują $\mathrm{w}$ ich własnych rodzinach, są też zatrudniane za najniższą stawkę wynagrodzenia jako pomoc domowa w gospodarstwach rodzin o wysokim statusie ekonomicznym. Wśród konsekwencji, jakie niesie za sobą konieczność podjęcia pracy przez nieletnich, są zarówno te psychologiczne, fizyczne, jak i społeczne. Obok zapadalności na wszelkiego rodzaju choroby oraz narażenia na urazy, konsekwencją pracy w okresie dzieciństwa jest też brak możliwości lub chęci kontynuowania obowiązku szkolnego i tym samym zyskania szansy na zmianę swojego położenia w przyszłości.

\section{Opieka zdrowotna}

Sytuacja dziecka w Maroku zależy w dużej mierze od kondycji rodziny i sytuacji jego matki oraz od dostępu do wody pitnej, jak też opieki zdrowotnej już od okresu prenatalnego. Ministerstwo Zdrowia Królestwa Maroka w 2018 roku opublikowało obszerny raport z badań dotyczących zdrowia

${ }^{60}$ Morocco, UNICEF Annual Report 2017, https://www.unicef.org/about/annualreport/ files/Morocco_2017_COAR.pdf, s.1. [dostęp: 29.11.2019].

${ }^{61}$ CommuniquédepresseduHaut-commissariatau Planàl'occasiondela Journéemondialecontreletravaildesenfants. Letravaildangereuxdesenfantsâgésde $7 a ̀ 17 a n s a u M a r o c, H a u t-C o m m i s s a r i a t a u P l a n d u$ Maroc.CentreNational deDocumentation, s.96; https://www.hcp.ma/Communique-de-pressedu-Haut-commissariat-au-Plan-a-l-occasion-de-la-Journee-mondiale-contre-le-travail-des-enfants_a2178.html [dostęp: 29.11.2019]. 
populacji Maroka, zatytułowany Enquête Nationale sur la Population et la Santé Familiale (ENPSF 2018). W rozdziale poświęconym okolicznościom porodu wskazano, że 70,2\% kobiet rodzi w placówkach publicznych, 15,7\% w placówkach prywatnych, a 13,4\% w domu. Zarówno porody domowe, jak i te $\mathrm{w}$ niewystarczająco wyposażonych placówkach publicznych niosą za sobą wysokie niebezpieczeństwo powikłań okołoporodowych i śmierci noworodków. Według deklaracji respondentów, 96,9\% niemowląt zostało zarejestrowanych $\mathrm{w}$ urzędzie stanu cywilnego. Nie odnotowano znaczących różnic pomiędzy rejestracją chłopców a rejestracją dziewczynek oraz pomiędzy środowiskami zamieszkania rodzin. Wyniki badań pokazują również, że znacząco spadła w Maroku śmiertelność wśród dzieci do lat 5 w stosunku do raportu z 2011 roku i aż o 74\% względem raportu z 1990 roku $^{62}$. Doniesienia prasowe z 2018 roku określają system marokańskiej prywatnej opieki zdrowotnej oraz publiczny jako niewydolne. Do najbardziej znaczących problemów w tym zakresie zaliczyć można konieczność uiszczania płatności za narzędzia i materiały opatrunkowe w publicznych szpitalach, wysokie i mimo wszystko złej jakości usługi, zwłaszcza w sektorze publicznym, ale też w sektorze prywatnym, oraz powszechną korupcję. Chociaż, jak podaje autorka artykułu Examples of Morocco's continually failing health care system (Przyktady nieustannie upadajacego systemu opieki zdrowotnej w Maroku), mimo iż Konstytucja Królestwa Maroka z 2011 roku gwarantuje równy dostęp do opieki medycznej, to w rzeczywistości większość pacjentów nie posiada środków na pokrycie wymaganych przez szpital kosztów, a 41,3\% populacji żyje na terenach wiejskich bez stałych dochodów lub wsparcia społecznego, co rzutuje na utrudniony dla tych obywateli dostęp do placówek opieki zdrowotnej ${ }^{63}$. Oficjalne dane statystyczne dotyczą głównie pełnej rodziny z zarejestrowanymi dziećmi. Badania przeprowadzane przez niezależne agendy dostarczają zupełnie odmiennych wyników. Charifa Zemouri, rezydująca w Amsterdamie doktorantka na wydziale stomatologii, wskazuje jeden z przykładów takich praktyk:

(...) niedawno opublikowane badanie przeprowadzone w regionie Bni Hssen śledziło system nadzoru śmierci matek przez 1,5 roku. Stwierdzono, że w ramach tego systemu systematycznie zaniżano liczbę zgonów matek w zakładach opieki zdrowotnej i poza nimi. Śmiertelność matek w badaniu była 2,5 razy wyższa niż zgłaszana przez lokalny system nadzoru. Może się zdarzyć, że ta forma zaniżania raportowanych da-

${ }^{62}$ Enquête Nationale sur la Population et la Santé Familiale(ENPSF 2018), Ministère de la santé Royaume du Maroc,s. 96-149. https://www.sante.gov.ma/Publications/Etudes_enquete/Pages/default.aspx, [dostęp: 29.11.2019].

${ }^{63}$ Ch. Zemouri, Examples of Morocco's continually failing heal th care system, 06.03 2018; https:/ / www.moroccoworldnews.com/2018/03/241860/morocco-continually-failing-health-care-system/, [dostęp:29.11.2019]. 
nych ma miejsce w całym kraju, co prowadzi do fałszywych sprawozdań na temat poprawy systemu opieki zdrowotnej dla matek ${ }^{64}$.

Powyższe badania wskazują, że dostęp do usług medycznych - dla matek i dzieci - nie jest ani w pełni gwarantowany, ani w pełni możliwy. Przyczynami są zła sytuacja w placówkach opieki zdrowotnej, jak też ubóstwo marokańskich rodzin. Jedną z form poprawy jakości działania tego systemu jest udział międzynarodowych organizacji pozarządowych i międzynarodowych dotacji, lecz bez dogłębnej reformy i rozwiązań systemowych zmiana obecnego stanu wydaje się niemożliwa.

\section{Edukacja marokańskiego dziecka}

Dostęp do edukacji w Maroku jest uwarunkowany: statusem dziecka, czynnikami ekonomicznymi, jak również uwarunkowaniami geograficznymi miejsca zamieszkania i przekonaniami rodziny o konieczności zapewnienia wykształcenia swojemu dziecku. Edukacja może przebiegać w placówkach typu zachodniego, będących dziedzictwem okresu głównie francuskiej kolonizacji Maroka w latach 1912-1956 i reformowanych w kolejnych dziesięcioleciach, gdzie językami wykładowymi są arabski, francuski i język tamazight. Edukacja może się też odbywać w szkołach koranicznych, organizowanych przy meczetach na terenie całego kraju i następnie na uniwersytetach prowadzących ten typ edukacji, gdzie obowiązuje klasyczny język arabski ${ }^{65}$. Oprócz sektora państwowego w Maroku funkcjonują również placówki prywatne, prowadzone przez stowarzyszenia i inne organizacje posiadające zezwolenie na taką działalność. Najnowszy raport UNESCO ${ }^{66}$ poświęcony edukacji - Right to education handbook - rozpoczyna stwierdzenie, że "edukacja nie jest przywilejem, ale jest prawem człowieka" (Education is not a privilege. It is a human right). Dostęp do edukacji przede wszystkim typu zachodniego jest w Maroku cały czas niewystarczający, w dużej mierze niesprawiedliwy i część dzieci nie podejmuje nauki nawet na poziomie podstawowym. Dane z 2010 roku wskazywały, że pomimo poprawy poziomu alfabetyzacji w Królestwie, zwłaszcza osób dorosłych, nadal 40\% dzieci i młodzieży marokańskiej od 10 roku życia wzwyż nie potrafi czytać

${ }^{64}$ Jest to raport Underreporting of deaths in the maternal deaths surveillance system in one region of Morocco autorstwa S. Abouchadi, W. Zhanga i V. De Brouwere'a, opublikowany 31 stycznia 2018 roku; https:/ / doi.org/10.1371/journal.pone.0188070.

${ }^{65}$ Zob. m.in.: E. Johnsson, Uwarunkowania społeczne i jezykowe; D.A. Wagner, A. Lotfi, Traditional Islamic Education in Morocco: Sociohistorical and Psychological Perspectives, Journal Articles (Literacy.org), 1980, 10; https:/ / repository.upenn.edu/literacyorg_articles/10,

${ }^{66}$ Right to education handbook, UNESCO and Right to Education Initiative (UK), 2019. 
i pisać. Na obszarach wiejskich w 2010 roku blisko 75\% kobiet pozostawało analfabetkami ${ }^{67}$.

Kolejne reformy edukacji, mimo wysiłków ze strony rządu i właściwych ministerstw, nie przynoszą spektakularnych efektów. W najtrudniejszej sytuacji znajdują się dzieci nierejestrowane, bez prawa do edukacji, a następnie te zamieszkujące wiejskie tereny górskie, gdzie odległość od placówki szkolnej i czasowa izolacja miejsca zamieszkania na skutek warunków klimatycznych - śniegu i powodzi, uniemożliwiają korzystanie z instytucjonalnej edukacji na podstawowym poziomie. Wiele marokańskich dzieci kończy jedynie szkołę podstawową głównie z przyczyn ekonomicznych lub konieczności podjęcia obowiązków rodzicielskich w tak młodym wieku. Edukacja uważana jest za jeden z czynników wspierających zmianę indywidualnych biografii, jednak by tak się stało, musi ona być powszechna i dostępna. System edukacji w Maroku to również narzędzie budowania postkolonialnej tożsamości, opartej na dylematach pomiędzy arabizacją, frankofońskim dziedzictwem i narodowo-wyzwoleńczymi dążeniami Imazighen.

\section{Zakończenie}

Powyższe przeglądowe rozważania rysują obraz dzieciństwa w Maroku jako czas przyjmowania ról dorosłych członków społeczeństwa i tworzą swego rodzaju mapę bieżących problemów tego kraju, determinujących jeden z najważniejszych okresów w życiu, jakim jest dzieciństwo. Uwikłanie dziecka w te problemy jest na ogół niezależne od niego, lecz uwarunkowane tradycją, religią oraz instytucjami i powoduje, że minimalny zakres stanowienia o sobie sprawia, że często jego życiowe losy są dramatyczne. W tym krótkim omówieniu powyższe problemy zostały jedynie zarysowane i wybrane arbitralnie jako te, które autorce wydają się dominujące i mogą stanowić podstawę do przyszłych dyskusji.

Nie ulega wątpliwości, że stan marokańskiej rodziny, a zwłaszcza funkcjonowanie matki, bezpośrednio wpływa na losy dziecka i jego późniejsze szanse na godną egzystencję. Należy jeszcze raz podkreślić, iż spolaryzowane społeczeństwo marokańskie umożliwia więc również szczęśliwe i beztroskie dzieciństwo w tym kraju. O ile o losy dzieci z rodzin uprzywilejowanych ekonomicznie możemy być spokojni, o tyle losy "niewidocznych” małych mieszkańców i migrantów na terenie Królestwa Maroka nie powinny być nam obojętne.

${ }^{67}$ S. Tawil, S. Cerbelle, A. Alama, Education au Maroc: analyse du secteur, UNESCO Office in Rabat, 2010, s. 8. 


\section{BIBLIOGRAFIA}

Asadulla A., Islam Vs. West: Fact or Fiction? A brief historical, political, theological, philosophical and psychological perspective, Wydawnictwo iUniverse, Bloomington 2008.

Chraïbi D., Obudź się matko!, przekł. M. Cywińska, R. Abou-Hilal, Wydawnictwo Imbir, Warszawa 2007.

Danecki J., Podstawowe wiadomości o islamie, Wydawnictwo Akademickie Dialog, Warszawa 2007.

Fraser Fujinga A., Islamic Law in Post-Revolutionary Iran, [w:] The Oxford Handbook of Islamic Law, red. M.E. Anver, A. Rumee, Oxford University Press, Oxford 2018.

Gittis D., Historia konstruktów dzieciństwa, [w:] Wprowadzenie do badań nad dzieciństwem, red. M.J. Kehily, przekł. ks. M. Kościelniak, Wydawnictwo WAM, Kraków 2008.

Hoffman K.E., Morocco, [w:] Filiation and the Protection of Parentless Children, red. N. Yassari, L.M. Möller, M.C. Najm, T.M.C. Asser Press, The Hague 2019.

Jelloun T.B., Co to jest islam?, Wydawnictwo Karakter, Kraków 2018.

Johnsson E., Uwarunkowania społeczne i jezzykowe dla edukacji w Maroku, [w:] Edukacja w warunkach globalnych i lokalnych. Konteksty i egzemplifikacje, red. A. Boroń, A. Mańkowska, C. Czech-Włodarczyk, P. Peret-Drążewska, Wydawnictwo Naukowe UAM, Poznań 2018.

Kehily M.J., Zrozumieć dzieciństwo: Wprowadzenie w kluczowe tematy i zagadnienia, [w:] Wprowadzenie do badań nad dzieciństwem, red. M.J. Kehily, przekł. ks. M. Kościelniak, Wydawnictwo WAM, Kraków 2008.

Machut-Mendecka E., Świat tradycji arabskiej, Wydawnictwo Psychologii i Kultury Eneteia, Warszawa 2005.

Machut-Mendecka E., Być dzieckiem arabskim, [w:] Dziecko w oriencie, red. D. Chmielowska, B. Grabowska, E. Machut-Mendecka, Wydawnictwo Akademickie Dialog, Warszawa 2013.

Malik ibn Anas, [w:] Maty stownik kultury świata arabskiego, red. J. Bielawski, Wiedza Powszechna, Warszawa 1971.

Mernissi F., Dzieciństwo w haremie. Sny o wolności, przekł. E. Skweres, Grupa Wydawnicza Bertelsmann Media, Warszawa 2001.

Sadiqi F., Morocco, [w:] S. Kelly, J. Breslin, Women's Rights in the Middle East and North Africa: Progress Amid Resistance, Wydawnictwo Freedom House; Lanham, MD: Rowman \& Littlefield, New York 2010.

Rhouni R., Secular and Islamic Feminist Critiques in the Work of Fatima Mernissi, Series: Women and Gender: The Middle East and the Islamic World, 2009, Volume: 9.

Sonneveld N., Divorce Reform in Egypt and Morocco: Men and Women Navigating Rights and Duties, Islamic Law and Society, 2019, 26.

El Fethouni Y., Hamelin N., The Effect of Media and Economics on The Change of Divorce rate in Morocco, International Journal of Academic Research and Reflection, 2016, 4, 3, Progressive Academic Publishing, UK, online, https:/ / www.idpublications.org/wp-content/uploads / 2016/03/Full-Paper-THE-EFFECT-OF-MEDIA-AND-ECONOMI CS-ON-THE-CHANGE-OF-DIVORCE-RATE-IN-MOROCCO.pdf ,s. 20-30. [dostęp: 10.02.2021].

Fiqh, [w:] Mały stownik kultury świata arabskiego, red. J. Bielawski, Wydawnictwo Wiedza Powszechna, Warszawa 1971. 


\section{Raporty i netografia}

2017-22: Child Marriages In Morocco,(2017), NGO KVINFO Denmark and Droit \& Justice (D\&J) Morocco, https://kvinfo.dk/mena/projects/2017-22-child-marriages-inmorocco/z?lang=en, [dostęp: 28.11.2019].

Abdennebi Z., Morocco struggles to curb rise in number of girls married underage, 26.04.2018 r., Reuters, online, https:/ / www.reuters.com/article/us-morocco-women-idUSKBN1HX22T, [dostęp: 10.02.2021].

Abouchadi S., Zhanga W., De Brouwere'a I.V., Underreporting of deaths in the maternal deaths surveillance system in one region of Morocco 2018; https://doi.org/10.1371/journal. pone. 0188070 .

Analyse. Ces nouveaux profils de la famille marocaine: Moins d'enfants, plus de maladies chroniques, L'Economiste, Edition No:3756 Le 05/04/2012, https://www.leconomiste.com/ article/893043-ces-nouveaux-profils-de-la-famille-marocaine-moins-d-enfants-plusde-maladies-chroniq,[dostęp: 29.11.2019].

Ben Saga A., Study: Child Marriages in Morocco Are Increasing, 09.01.2019 r., Morocco World News, online, https://www.moroccoworldnews.com/2019/01/262828/studychild-marriages-in-morocco-are-increasing/, [dostęp: 10.02.2021].

Bourqia R. i in., Société, famille, femmes et jeunes, 50 ans de développement humain et perspectives, Cinquantenaire de l'Indépendance du Royaume du Maroc, ISBN 9954-405-22-4, Nº́pôt Légal, 2005/2614, Royaume du Maroc.

Chraibi Driss, CBC Arts, Moroccan-French novelist Driss Chraibi dies, 02.04.2007 r. online, https://www.cbc.ca/news/entertainment/moroccan-french-novelist-driss-chraibi-dies-1.665040, [dostęp: 08.02.2021].

Communiqué de presse du Haut-commissariat au Plan à l'occasion de la Journée mondiale contre le travail des enfants. Le travail dangereux des enfants âgés de 7 à 17 ans au Maroc, (2018) Haut-Commissariat au Plan du Maroc. Centre National de Documentation. https:// www.hcp.ma/Communique-de-presse-du-Haut-commissariat-au-Plan-a-l-occasionde-la-Journee-mondiale-contre-le-travail-des-enfants_a2178.html [dostęp: 29.11.2019].

Cunningham H., Avner Gil'adi: Children of Islam: concepts of childhood in medieval Muslim society. (St Antony's/Macmillan Series.) xii, 176 pp. Basingstoke and London: Macmillan Academic and Professional Ltd., 1992. £40., Bulletin of the School of Oriental and African Studies, Get access, February 1994, 57, 1.

Démographie: famille au maroc: les réseaux de la solidarité familiale, Famille au Maroc: les réseaux de la solidarité familiale. Avant-propos, 16/03/2011, Haut-Commissariat au Plan du Maroc, Centre National de Documentation, 2011. s.2. https:/ / www.hcp.ma/downloads/ Demographie-Famille-au-Maroc-les-reseaux-de-la-solidarite-familiale_t13086.html, [dostęp: 29.11.2019].

Enquête Nationale sur la Population et la Santé Familiale, Ministère de la santé Royaume du Maroc, 2018; https://www.sante.gov.ma/Publications/Etudes_enquete/Pages/default.aspx, [dostęp: 29.11.2019].

Fiqh, Encyclopaedia Britannica, online; https://www.britannica.com/topic/fiqh, [dostęp: 08.02.2021].

Gandolfi P., Multiple families in changing societies in the Maghreb: The case of Morocco, DIFI Family Research and Proceedings, 2015:7 http://dx.doi.org/10.5339/ difi.2015.7.

Horloge de la population, Haut-Commissariat au Plan du Maroc. Centre National de Documentation, 2019; www.hcp.ma.[dostęp: 27.11.2019].

Kafala, Komisja Europejska, AD HOC QUERY ON 2019.88 Kafala children, Requested by EMN NCP Spain on 4 October 2019, Responses from Austria, Belgium, Croatia, Cy- 
prus, Czech Republic, Estonia, Finland, Germany, Hungary, Ireland, Italy, Latvia, Lithuania, Luxembourg, Malta, Netherlands, Poland, Slovakia, Spain, Sweden, United Kingdom plus Norway (22 in Total), online, https:/ / ec.europa.eu/home-affairs/ sites/homeaffairs/files/201988_kafala_children.pdf, [dostęp: 10.02.2021].

Les enfants au Maroc. Des progrès et des défis (2015), UNICEF; https:/ / www.unicef.org/morocco/rapports/analyse-de-la-situation-des-enfants-au-maroc/les-enfants-au-maroc, [dostęp: 27.11.2019].

Morocco - Regional Study on Child Marriage, UNICEF, s. 6-7., online, https:/ /www.unicef. org/morocco/media/181/file/Mariage \%20des\%20enfants\%20au\%20Maroc.pdf, [dostęp: 10.02.2021].

Morocco, UNICEF Annual Report 2017; https://www.unicef.org/about/annualreport/ files/Morocco_2017_COAR.pdf, s.1. [dostęp:29.11.2019].

Morocco. Situation of Unaccompanied Minors. Report 2/2017, Report based on interviews in Morocco, 9 to 18 October 2016, (2017),Ministry of Immigration and Integration. The Danish Immigration Service. Copenhagen.

Mudawwanat al-Usra al-Maghribiyya-Wizarat al-'Adl wa al-Hurriyat-Al-Mumlaka Al-Maghribiyya/Code de la Famille-Ministe`re de la Justice et des Libertes-Royaume du MarocDahir n. 1-04-22 du 12 Hija 1424 (3 Fevrier 2004) portant promulgation de la Loi n. 70-03 portant Code de la Famille.

Naqrachi A., Early Marriage in Morocco, [w:] A New Paradigm: Perspectives on the Changing Mediterranean, red. S. Toperich, A. Mullins, Center for Transatlantic Relations SAIS, 2014.

Rachik H., Bourquia R., Bencherifa A., Tozy M., Rapport de synthèse de l'enquête nationale sur les valeurs, 50 ans de développement humain et perspectives, Cinquantenaire de l'Indépendance du Royaume du Maroc, Dépôt Légal 2005/2602, Royaume du Maroc 2004.

Report: Morocco: Marriage and divorce legal and cultural aspects (2017), The Norwegian Country of Origin Information Centre Landinfo, 21.04. 2017, online; https://landinfo.no/wp-content/uploads/2018/04/Morocco-Marriage-and-divorce-legal-andcultural-aspects-21042017-final.pdf, [dostęp: 10.02.2021].

Right to education handbook, UNESCO and Right to Education Initiative (UK), 2019.

Street children of Morocco, NGO Humanium, 2019; https://www.humanium.org/en/ street-children-of-morocco-2/, [dostęp: 29.11.2019].

Tawil S., Cerbelle S., Alama A., Education au Maroc: analyse du secteur, UNESCO Office in Rabat, 2010.

Wagner D.A., Lotfi A., Traditional Islamic Education in Morocco: Sociohistorical and Psychological Perspectives, Journal Articles (Literacy.org), 1980, 10; https://repository.upenn. edu/literacyorg_articles/10,

Zemouri Ch., Examples of Morocco's continually failing health care system, Morocco World News, 06.03 2018; https://www.moroccoworldnews.com/2018/03/241860/morocco-continually-failing-health-care-system/, [dostęp:29.11.2019]. 